\title{
NON-GONOCOCCAL URETHRITIS IN THE MALE TREATED WITH TETRACYCLINE*
}

\author{
BY \\ G. O. MAYNE \\ Special Clinic, Royal Infirmary, Edinburgh
}

The Report of the Chief Medical Officer of the Ministry of Health for 1955 (Ministry of Health, 1956) states that the number of cases of nongonococcal urethritis in male patients increased during that year to a total of 14,269 , and that the incidence of this condition exceeded that of gonorrhoea $(14,079$ cases). For this reason, and because the treatment of non-gonococcal urethritis has in the past proved unsatisfactory, any promising new therapy deserves the fullest investigation.

In the series about to be described, 109 consecutive cases of non-gonococcal urethritis were each treated with $250 \mathrm{mg}$. tetracycline hydrochloride in capsule form every 6 hours for 5 days, i.e. a total dose of $5 \mathrm{~g}$.

\section{Material}

It was found possible to divide the total of 109 cases into two approximately equal groups after microscopic examination of the urethral discharge; 56 were classified as "abacterial" because no visible micro-organisms (including Trichomonas vaginalis) were present, and 53 were included in a heterogeneous group classified as "bacterial urethritis" in which bacteria other than gonococci were found.

This division of non-gonococcal urethritis into abacterial and bacterial urethritis appears valid at the present time since it seems likely that the causes of these conditions may be different. It must, however, be admitted that in many cases the organisms found in bacterial urethritis may be either secondary invaders or commensals rather than the primary infecting agents, but it is felt that they should be considered causative if present in appreciable numbers and in the absence of any other recognizable cause. From a study of the incubation periods in this series, there emerges nothing to support the suggestion that the abacterial cases may merely represent the earliest stages of the same condition, before secondary infection becomes manifest.

\section{Results of Treatment}

The response to treatment was arbitrarily classified as "Good", "Moderate", or "Failure". The response was regarded as "good" when the discharge disappeared and the urine became clear in less than 7 days, whereas those cases classified as "failures"

* Received for publication July 16, 1957. showed no response to treatment or relapsed immediately afterwards. Cases in which an immediate and lasting improvement followed treatment, but in which complete cure was delayed longer than 7 days or in which adjuvant therapy was necessary (e.g. urethral irrigations) were regarded as having shown a "moderate" response.

The majority of cases were subsequently observed over a period of 3 months following treatment, but a relatively small number has been included in which the period of observation was less, since in our experience apparent relapse after the urine has become clear is distinctly less common than is failure to respond in the first instance.

The results of treatment (Table I) show that in the cases exhibiting a "good" response the difference between abacterial (75 per cent.) and bacterial urethritis (56 per cent.) is sufficiently large to be striking, amounting to almost 20 per cent. This tends to support the suggestion made earlier that the aetiological agents may be different, although there is a one-in-twenty possibility that such a finding might be due to chance alone.

TABLE I

RESULTS OF TREATMENT IN 109 CASES

\begin{tabular}{|c|c|c|c|c|c|c|c|c|}
\hline \multirow[b]{2}{*}{$\begin{array}{l}\text { Type of } \\
\text { Urethritis }\end{array}$} & \multicolumn{2}{|c|}{ Good } & \multicolumn{2}{|c|}{ Moderate } & \multicolumn{2}{|c|}{ Failure } & \multicolumn{2}{|c|}{ Total } \\
\hline & $\begin{array}{c}\text { No. } \\
\text { of } \\
\text { Cases }\end{array}$ & $\begin{array}{c}\text { Per } \\
\text { cent. }\end{array}$ & $\begin{array}{c}\text { No. } \\
\text { of } \\
\text { Cases }\end{array}$ & $\begin{array}{c}\text { Per } \\
\text { cent. }\end{array}$ & $\begin{array}{c}\text { No. } \\
\text { of } \\
\text { Cases }\end{array}$ & $\begin{array}{c}\text { Per } \\
\text { cent. }\end{array}$ & $\begin{array}{c}\text { No. } \\
\text { of } \\
\text { Cases }\end{array}$ & $\begin{array}{c}\text { Per } \\
\text { cent. }\end{array}$ \\
\hline Abacterial & 42 & 75 & 12 & $21 \cdot 4$ & 2 & $3 \cdot 6$ & 56 & 100 \\
\hline Bacterial & 30 & $56 \cdot 6$ & 20 & $37 \cdot 7$ & 3 & $5 \cdot 7$ & 53 & 100 \\
\hline All Cases & 72 & $\overline{66 \cdot 1}$ & 32 & $29 \cdot 3$ & 5 & $4 \cdot 6$ & 109 & 100 \\
\hline
\end{tabular}

The success rate of 75 per cent. in abacterial urethritis is considerably better than that obtained with any other form of treatment in our hands, and it is suggested that, whatever treatment is favoured for bacterial urethritis, the diagnosis by microscopy of abacterial urethritis should be regarded as an indication for the use of tetracycline. This has the disadvantage of being expensive, but against this must be set the facts that it undoubtedly reduces the duration of treatment, and that it is probably 
instrumental in preventing systemic complications and Reiter's syndrome in an unknown proportion of cases.

\section{Undesirable Reactions}

The nature and incidence of undesirable sideeffects during tetracycline therapy are shown in Table II.

TABLE II

INTOLERANCE (109 CASES)

\begin{tabular}{|c|c|c|c|}
\hline \multirow{2}{*}{ Side-Effect } & & \multicolumn{2}{|c|}{ Cases } \\
\hline & & Number & Per cent. \\
\hline $\begin{array}{l}\text { Mild diarrhoea } \\
\text { Severe diarrhoea }+ \text { vomiting } \\
\text { Sore tongue (erosive glossitis) } \\
\text { Peri-anal irritation } \quad \ldots\end{array}$ & $\begin{array}{l}\cdots \\
\cdots \\
\cdots\end{array}$ & $\begin{array}{l}7 \\
1 \\
1 \\
1\end{array}$ & $\begin{array}{l}6 \cdot 4 \\
0.9 \\
0.9 \\
0.9\end{array}$ \\
\hline
\end{tabular}

In only one case, in which violent vomiting and diarrhoea developed on the 4th day, did treatment have to be suspended permanently. The outcome in this instance was nevertheless good.

It seems clear, therefore, that when short-term tetracycline therapy is employed for a period not longer than 5 days undesirable side-effects are neither common nor troublesome.

\section{Effects of Previous Treatment}

Eleven of the abacterial cases had undergone previous treatment with irrigations, penicillin, sulphonamide, and streptomycin, either alone or in combination. In six of these cases the response to subsequent tetracycline was good.

Eighteen cases of bacterial urethritis had likewise been treated with irrigations, penicillin, or sulphonamide, singly or in combination. In ten, subsequent tetracycline therapy produced good results.

These numbers are small, but we derived the clinical impression that previous unsuccessful therapy in abacterial urethritis reduced the likelihood of a satisfactory response to tetracycline. If on further experience this proves to be the case, it will reinforce our belief that tetracycline should be employed in the first instance in all cases of abacterial urethritis. In any event, the success of tetracycline in over a half of all these previously-treated cases justified its use.

\section{Examination of Consorts}

Examination of the female consort was carried out in eighteen instances, eleven of the abacterial group and seven of the bacterial group. Of the former, seven harboured Trichomonas vaginalis, one exhibited Candida albicans infection, and three showed no abnormality. Of the latter, three harboured Trichomonas vaginalis, one had a cervical erosion, and three showed no abnormality.

The number of cases of Trichomonas vaginalis infestation among the consorts, especially the consorts of cases of abacterial urethritis, is of interest (ten cases out of eighteen). Nevertheless it is not suggested that this organism plays a major part in the causation of urethritis in the male for the following reasons:

(1) Experienced observers report an incidence of Trichomonas vaginalis infestation of no more than 6 per cent. in males with urethritis (Batchelor and Murrell, 1951; Lanceley, 1953; Lydon, 1955). This is in keeping with our own experience. Presumably, therefore, the urethritis in the remaining 94 per cent. is due to some other cause.

(2) As exemplified in this series, the majority of cases of abacterial urethritis respond to tetracycline therapy, whereas this antibiotic is of doubtful value, at least when given systemically, in the treatment of Trichomonas vaginalis infestation in the female.

(3) Trichomonas infestation is common in the female, although Reiter's syndrome, a recognized complication of non-gonococcal urethritis, is almost confined to the male sex.

\section{Summary}

(1) In South-east Scotland non-gonococcal urethritis is composed of approximately equal "bacterial" and "abacterial" groups.

(2) Tetracycline is a very effective therapy for abacterial urethritis; it appears to be significantly less successful in bacterial urethritis. This suggests that these two conditions may be due to different causes.

(3) When a course of therapy extending over a period of only 5 days is given, undesirable sideeffects with tetracycline are insignificant.

(4) Previous unsuccessful therapy appears to reduce the likelihood of a satisfactory response in abacterial urethritis, but apparently does not affect the outcome in bacterial urethritis.

(5) There is a high proportion of Trichomonas vaginalis infestation in the female consorts of male cases of urethritis, especially cases of abacterial urethritis. It is not suggested, however, that Trichomonas vaginalis plays a major part in the causation of urethritis in the male.

I wish to thank Dr. Robert Lees for permission to publish this article.

\section{REFERENCES}

Batchelor, R. C. L., and Murrell, M. (1951). "Venereal Diseases described for Nurses". Livingstone, Edinburgh.

Lanceley, F. (1953). British Journal of Venereal Diseases, 29, 213.

Lydon, F. L. (1955). Brit. med. J., 2, 1447.

Ministry of Health (1956). "Report for the Year ended 31st December 1955", Part 2, p. 64. Cmnd 16. H.M.S.O., London. 